abnormal motility, at least in infancy, and the very slow passage of barium in the barium follow-through at age 18 months supports this. The abnormality in motility would be the main factor that predisposed to small intestinal bacterial overgrowth, but the secondary acquisition of achlorhydria would exacerbate this. At the time of her acute admission at age 15 months a secondary acute enterocolitis was present too. We have not been able to demonstrate a primary immune defect. It seems likely that some malabsorption will be a permanent feature of this child's life, but at the moment her increased appetite enables her to absorb enough to thrive despite persistent steatorrhoea.

I thank Dr W R McAinsh and Professor F Cockburn for permission to report this case.

\section{References}

1 Larcher V F, Shepherd R, Francis D E M, Harries J T. Protracted diarrhoea in infancy. Arch Dis Child 1977; 52: 597-605.

2 Ogilvie D, McCollum J P K, Packer S, et al. Urinary outputs of oxalate, calcium, and magnesium in children with $9 . \sqrt{ }$ intestinal disorders. Potential cause of renal calculi. Arch Dis Child 1976; 51 : 790-5.

3 Gracey M, Cullity G J, Suharjono, Sunoto. The stomach in malnutrition. Arch Dis Child 1977; 52: 325-7.

4 Smythe P M, Schonland M, Brereton-Stiles G G, et al. Thymolymphatic deficiency and depression of cell mediated immunity in protein-calorie malnutrition. Lancet 1971; ii: 939-44.

5 Kenworthy R. Effect of Escherichia coli on germ-free and gnotobiotic pigs. I. Light and electron microscopy of the small intestine. J Comp Pathol 1970; 80: 53-63.

Correspondence to Dr J F B Dossetor, Queen Elizabeth Hospital, Gayton Road, King's Lynn, Norfolk PE30 4ET.

Received 19 June 1980

\title{
Delayed separation of the umbilical cord, severe widespread infections, and immunodeficiency
}

\author{
J G BISSENDEN, M R HAENEY, M J TARLOW, AND R A THOMPSON
}

\begin{abstract}
Department of Paediatrics and Child Health, and Regional Immunology Laboratory, East Birmingham Hospital, Birmingham
\end{abstract}

SUMMARY Three of 4 children in a family died from infection before age one year. All 3 had delayed separation of the umbilical cord in the third week. One child was found to have defects both in specific antibody production and in neutrophil function; these were not improved by treatment with ascorbic acid or levamisole.

Hayward et al. ${ }^{1}$ described a new familial syndrome of delayed separation of the umbilical cord, widespread infections, and defective neutrophil mobility. They suggested that the isolated defect in neutrophil mobility could be corrected in vitro and in vivo by ascorbic acid. We report a family with an apparently similar clinical syndrome; however, in the child studied the immunological defect was more extensive and affected both neutrophil function and specific antibody production, and was not improved by treatment with ascorbic acid or levamisole.

\section{Case report}

A girl weighing $3 \mathrm{~kg}$ was born by caesarean section. She was the fourth child of healthy unrelated white parents. After slight neonatal asphyxia, she fed poorly from birth, and developed diarrhoea during the first week of life. The umbilical cord did not separate until the third week, leaving an imperfectly healed stump. At age 4 weeks she developed an axillary abscess which healed spontaneously, followed by a staphylococcal abscess on the chest wall requiring surgical incision and a course of flucloxacillin. She had a mild anaemia with a total white cell count of $45 \pm 10^{9} / 1$, of which $90 \%$ were neutrophils.

The family history is remarkable. The first child had died suddenly after 10 weeks, having previously been well; necropsy examination showed clostridial septicaemia due to gangrenous ileo-caecitis. The second child had died at age 7 weeks from overwhelming staphylococcal infection and necropsy had shown peritonitis complicating necrotising enterocolitis. The umbilical cords of both children had failed to separate until the third week of life. Both parents and the third sibling, whose cord separated normally, are well.

In view of this family history of unusual infection, the patient was transferred for immunological investigation at age 2 months, as a possible case of 
Table 1 Tests of humoral and cell-mediated immunity

\begin{tabular}{|c|c|c|c|c|c|c|c|c|c|c|c|}
\hline \multirow{3}{*}{$\begin{array}{l}\text { Age } \\
\text { (months) }\end{array}$} & \multicolumn{3}{|c|}{ Serum immunoglobulin $(g / l)$} & \multicolumn{2}{|c|}{ Antibody activity } & \multirow{3}{*}{$\begin{array}{l}\text { Peripheral } \\
\text { blood } \\
\text { lymphocyte } \\
\text { count }\left(\times 10^{9} / l\right)\end{array}$} & \multicolumn{3}{|c|}{$\begin{array}{l}\text { Lymphocyte subpopulations* } \\
(\%)\end{array}$} & \multirow{2}{*}{\multicolumn{2}{|c|}{$\begin{array}{l}\text { Lymphocyte } \\
\text { transformation } \\
\text { ratiot }\end{array}$}} \\
\hline & \multirow{2}{*}{$I g G$} & \multirow[t]{2}{*}{$\operatorname{Ig} A$} & \multirow[t]{2}{*}{$\operatorname{Ig} M$} & \multirow[t]{2}{*}{ E. coli } & \multirow[t]{2}{*}{ Isoagglutinins } & & & & & & \\
\hline & & & & & & & $\begin{array}{l}E- \\
\text { rosetting } \\
\text { cells }\end{array}$ & $\begin{array}{l}\text { EAC- } \\
\text { rosetting } \\
\text { cells }\end{array}$ & $\begin{array}{l}\text { SmIg- } \\
\text { positive } \\
\text { cells }\end{array}$ & $P H A$ & $\boldsymbol{P W M}$ \\
\hline 2 & $\begin{array}{l}6 \cdot 10 \\
(2 \cdot 70-7 \cdot 60)\end{array}$ & $\begin{array}{l}0.05 \\
(0.05-0.55)\end{array}$ & $\begin{array}{l}0.45 \\
(0.15-0.65)\end{array}$ & Negative & Negative & $9 \cdot 70$ & $\begin{array}{l}52 \\
(60-80)\end{array}$ & $\begin{array}{l}28 \\
(15-30)\end{array}$ & $\begin{array}{l}16 \\
(5-15)\end{array}$ & $13(6)$ & $4(3)$ \\
\hline 5 & $\begin{array}{l}9 \cdot 30 \\
(2 \cdot 10-11 \cdot 25)\end{array}$ & $\begin{array}{l}0.15 \\
(0.10-0.95)\end{array}$ & $\begin{array}{l}1 \cdot 70 \\
(0 \cdot 15-0.85)\end{array}$ & Negative & Negative & $11 \cdot 80$ & 69 & & & $91(58)$ & \\
\hline 8 & $\begin{array}{l}16 \cdot 35 \\
(4 \cdot 80-15 \cdot 50)\end{array}$ & $(0 \cdot 20-1 \cdot 00)$ & $\begin{array}{l}1 \cdot 70 \\
(0 \cdot 25-1 \cdot 45)\end{array}$ & Negative & Negative & & & & & & \\
\hline
\end{tabular}

Immunoglobulin levels shown in brackets represent normal values for age.

- Results expressed as a percentage of lymphocytes forming non-immune rosettes with sheep erythrocytes (E rosettes), bearing receptors for C3b (EAC rosettes), or expressing surface membrane immunoglobulin (SmIg) by direct immunofluorescence. 7 Normal range shown in brackets. $\dagger$ Results expressed as a ratio of radioactive counts/minute obtained by incubating lymphocytes in the presence of phytohaemagglutinin (PHA) or pokeweed mitogen (PWM) to the counts obtained in culture medium alone. 2 Values for a healthy adult control shown in brackets.

Table 2 Tests of neutrophil function

\begin{tabular}{|c|c|c|c|c|c|c|}
\hline \multirow{2}{*}{$\begin{array}{l}\text { Age } \\
\text { (months) }\end{array}$} & \multicolumn{2}{|c|}{ Neutrophil mobility* } & \multicolumn{2}{|c|}{ NBT reduction $\dagger$} & \multirow{2}{*}{$\begin{array}{l}\text { Staphylococcal } \\
\text { bacteridical index } \ddagger\end{array}$} & \multirow{2}{*}{$\begin{array}{l}\text { Leucocyte } \\
\text { iodination test } \S\end{array}$} \\
\hline & Medium alone & Casein-stimulated & Unstimulated & Endotoxin-stimulated & & \\
\hline 2 & & & $\begin{array}{l}26 \\
(\mathrm{NR}<10)\end{array}$ & $\begin{array}{l}45 \\
(\mathrm{NR}>30)\end{array}$ & $\begin{array}{l}0.10 \\
(\mathrm{NR}<0.20)\end{array}$ & \\
\hline 5 & $25(37)$ & $28(148)$ & 27 & 44 & & $0 \cdot 70(2 \cdot 70)$ \\
\hline 6 & $18(17)$ & $30(90)$ & & & & \\
\hline 7 & $17(37)$ & 25 (129) & & & & \\
\hline 8 & $26(55)$ & 43 (127) & & & 0.04 & $0.77(3.35)$ \\
\hline
\end{tabular}

NR = normal range.

* Distance moved in $\mu \mathrm{m}$ by leading front method 2 in medium alone and in the presence of casein $(5 \mathrm{mg} / \mathrm{ml})$ as a chemoattractant. Value for a healthy adult control shown in brackets.

+ Percentage of neutrophils showing reduction of nitroblue tetrazolium (NBT) before and after endotoxin stimulation.2

¥ Ratio of ingested staphylococcal colony count after 140 minutes' incubation to colony count after 20 minutes' incubation. ${ }^{2}$

$\S$ Results expressed as the percentage of radiolabelled inorganic iodide converted to an intracellular protein-bound form during the phagocytosis of zymosan. 4 Value for a healthy adult control shown in brackets.

severe combined immunodeficiency. This diagnosis was excluded by the normal or raised proportions and absolute numbers of T- and B-lymphocytes in peripheral blood, normal lymphocyte transformation to non-specific plant mitogens (phytohaemagglutinin and pokeweed mitogen), and normal serum immunoglobulin levels (Table 1). The absence of serum isohaemagglutinins (blood group O Rh-positive) and lack of antibodies to Escherichia coli, were not considered unusual at this age. After a further course of intravenous antibiotics she was discharged home on oral fusidic acid, but her white cell count remained $>50 \times 10^{9} / 1$.

By age 5 months, she had suffered further staphylococcal abscesses, a possible bacterial meningitis (organism not isolated), and had a chronic umbilical discharge. She was persistently pyrexial, unwell, and had gained no weight. To eradicate any possible anaerobic organisms in the umbilical discharge, she was treated with intravenous clindamycin and metronidazole, but although the discharge dried up and the fever subsided, her white cell count remained $>50 \times 10^{9} / 1$. Further immunological investigations (Table 2) showed impaired neutrophil mobility but a normal capacity to reduce nitrobluetetrazolium (NBT). Both parents and her sibling had normal neutrophil mobility. Her serum IgM level was raised but serum $\operatorname{IgA}$ was in the low normal range for age (Table 1). Functional haemolytic activity of the classical complement pathway (CH50), and immunochemical $\mathrm{C} 3$ and $\mathrm{C} 4$ component levels were normal.

Because of the similarity of this case to the syndrome described by Hayward et al., ${ }^{1}$ the in vitro effect of ascorbic acid on neutrophil mobility was investigated. Preincubation of the patient's polymorphs in ascorbic acid at concentrations ranging from 1 to $50 \mathrm{mmol} / \mathrm{l}$ failed to enhance their migration towards a standard chemoattractant ${ }^{2}$ (casein 5 $\mathrm{mg} / \mathrm{ml})$. Despite this negative in vitro response, the patient was given a therapeutic trial of ascorbic acid (500 mg/day) for 6 weeks. Because levamisole may 
improve neutrophil mobility in certain disorders of phagocytic function, ${ }^{3}$ she was also given levamisole (30 mg/week) for 3 months. There was no reduction in the severity or frequency of infections and immunological reassessment (Table 2) confirmed the persistent impairment of neutrophil mobility although the patient's serum generated adequate cytotaxin in crossover experiments. Staphylococcal bacteriocidal activity was within normal limits. However, the defect was not confined to neutrophil mobility since leucocyte iodination ${ }^{4}$ was impaired compared with control cells. This test measures the percentage of radiolabelled inorganic iodide converted to an intracellular protein-bound form during the phagocytosis of zymosan and is thought to reflect neutrophil myeloperoxidase activity. ${ }^{4}$ In healthy adults between $2 \cdot 1$ and $5 \cdot 2 \%$ of the administered radioiodine is incorporated into the polymorphs. We have no comparable normal range for age-matched subjects but infants studied to date, in whom a neutrophil defect was eventually excluded after a battery of tests, all had values in excess of $1.7 \%$.

At 9 months, her serum IgA was low despite recurrent infections at mucosal surfaces; in contrast serum IgG and IgM were raised (Table 1). Antibodies to blood group substances, E. coli, and staphylococcus were still absent at an age when specific antibody activity is generally detectable. Replacement of intramuscular immunoglobulins was added to her treatment but despite further courses of antibiotics and a blood transfusion her condition deteriorated and she died. At necropsy she was found to have a mediastinitis and a perforated oesophagus, a partially patent urachus, and evidence of previous peritonitis. Apart from macroscopic thymic atrophy and hepatosplenomegaly, there were no specific histological abnormalities in the peripheral or intestinal lymph nodes, thymus, liver, spleen, or bone marrow.

\section{Discussion}

Hayward et al. ${ }^{1}$ identified 6 infants from two families with delayed separation of the umbilical cord; severe bacterical infections developed in 5 of them. The two infants they tested had defective neutrophil mobility with normal NBT reduction, and normal staphylococcal phagocytosis and killing. Subsequently, Bowen et al..$^{5}$ reported 2 unrelated patients with a similar problem: each had difficult cord separation and impairment of neutrophil chemotaxis but additionally showed defective leucocyte adherence and abnormal monocyte chemotaxis. Our patient had clinical features in common with these reports- namely the probable family history of recurrent infection associated with delayed cord separation and defective neutrophil mobility in the propositus. In contrast however, there was (a) a lack of an in vitro or in vivo response to high dose ascorbic acid therapy for 6 weeks, (b) an additional impairment of the leucocyte iodination test suggesting abnormal leucocyte myeloperoxidase activity, (c) probable selective IgA deficiency, and (d) lack of specific antibody synthesis.

Macrophages have an important role both in antigen processing for induction of a specific immune response and in T- and B-lymphocyte co-operation. Although formal tests of macrophage function are not readily available, the poor antibody responses in the presence of normal lymphocyte subpopulations and normal serum IgG and IgM levels may reflect a failure in macrophage function similar to that proposed in the Wiskott-Aldrich syndrome. ${ }^{6}$ Finally, the abnormal leucocyte iodination found in our patient and the defective leucocyte adherence reported by Bowen et al. ${ }^{5}$ suggest a more generalised abnormality of phagocytic cells. In our view, therefore, the immunological component of the syndrome is not restricted solely to neutrophil mobility as first suggested. ${ }^{1}$

\section{References}

1 Hayward A R, Harvey B A M, Leonard J, Greenwood M C, Wood C B S, Soothill J F. Delayed separation of the umbilical cord, widespread infections, and defective neutrophil mobility. Lancet 1979; i: 1099-101.

2 Wilkinson P C. Neutrophil leucocyte function tests. In: Thompson $\mathbf{R}$ A, ed. Techniques in clinical immunology. Oxford: Blackwell Scientific, 1977: 201-18.

3 De Cree J, Emmery L, Timmermans J, Eeckels R, De Cock W, Verhaegen H. Defective neutrophil chemotaxis and raised serum IgE levels in a child with recurrent bacterial infections and eczema: influence of levamisole. Arch Dis Child 1978; 53: 144-9.

4 Pincus S H, Klebanoff S J. Quantitative leukocyte iodination. N Engl J Med 1971 ; 284: 744-50.

5 Bowen J, Ochs H D, Wedgwood R J. Letter: Chemotaxis and umbilical separation. Lancet 1979; ii: 302.

- Blaese R M, Strober W, Brown R S, Waldmann T A. The Wiskott-Aldrich syndrome: a disorder with a possible defect in antigen processing or recognition. Lancet 1968; i: $1056-61$.

7 Waller C A, MacLennan I C M. Analysis of lymphocytes in blood and in tissues. In: Thompson R A, ed. Techniques in clinical immunology. Oxford: Blackwell Scientific, 1977: 176-200.

Correspondence to Dr J G Bissenden, Department of Paediatrics, Dudley Road Hospital, Dudley Road, Birmingham $\mathrm{B} 18 \mathrm{QQH}$.

Received 12 May 1980 